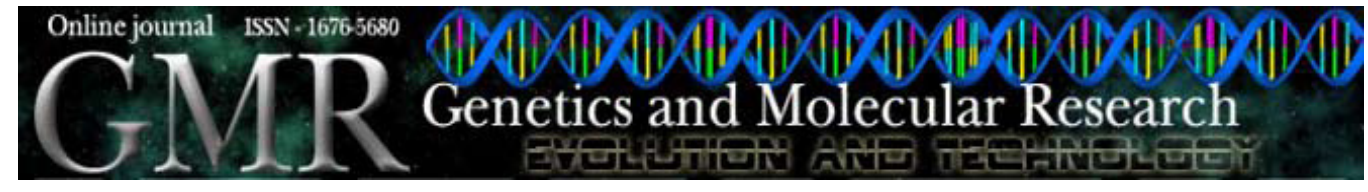

\title{
Genetic evaluation of the HSP70 protein in the Japanese quail (Coturnix japonica)
}

\author{
H.C.T. Gaviol ${ }^{1}$, E. Gasparino ${ }^{2}$, A.J. Prioli ${ }^{1}$ and M.A.M. Soares ${ }^{3}$ \\ ${ }^{1}$ Departamento de Genética e Melhoramento, Universidade Estadual de Maringá, \\ Maringá, PR, Brasil \\ ${ }^{2}$ Departamento de Zootecnia, Universidade Estadual de Maringá, \\ Maringá, PR, Brasil \\ ${ }^{3}$ Departamento de Biotecnologia, Universidade Estadual do Oeste do Paraná, \\ UNIOESTE, Cascavel, PR, Brasil \\ Corresponding author: H.C.T. Gaviol \\ E-mail: heloctgavioli@yahoo.com.br
}

Genet. Mol. Res. 7 (1): 133-139 (2008)

Received August 11, 2007

Accepted January 5, 2008

Published February 12, 2008

\begin{abstract}
Heat stress is one of the main problems in modern aviculture, since it affects birds especially in the final phase of rearing, causing bird mortality and economic losses to the aviculturist. The quail, as most birds, has difficulties in dissipating heat. However, little is known about the mechanism that controls the responses of the organism to stressor agents. Therefore, the study of heat shock proteins (HSPs) in these birds is important. A 960-bp portion of HSP70 was amplified using oligonucleotide primers specific for chickens. The fragment was sequenced, since it was the same protein, although some modifications have been observed. It showed 98\% homology with HSP70 stress protein in Gallus gallus and 99\% homology with Numida meleageris.
\end{abstract}

Key words: HSP70; Coturnix japonica; Sequencing 


\section{INTRODUCTION}

Quails are small birds that have a fast growth process and a meat with excellent quality and high level of proteins (Corradello, 1990), besides being docile and easy to handle. In Brazil, the domestic quail (Coturnix japonica) was introduced in the beginning of the 1960s (Murakami and Ariki, 1998; Oliveira, 2001).

Raising quail has been characterized as an activity that needs lower start-up investment, the use of small areas and little labor force, not to mention that it has a short reproductive cycle, regular posture, and good fertility and sexual precocity (Oliveira et al., 2002). Its commercialization is recent in Brazil, compared to other countries (Corradello, 1990).

Heat stress in birds is one of the main concerns in the aviculturist industry, since it causes high mortality and/or low productivity, especially during the warmest seasons (Mazzi et al., 2003).

In response to thermal stress in the tissues of living animals, cells synthesize proteins of low molecular weight that have specific functions on cell growth and in reversing or preventing damage caused by stress. These proteins, whose synthesis is increased when the cell is submitted to a stressful condition, are called heat shock proteins or HSPs (Hernandes et al., 2002).

The response of various organisms to thermal shock is one of the most highly conserved genetic systems known to date. Although stress proteins are not among the most abundant, they include one of the most conserved protein families found in different organisms (Parsell and Lindquist, 1993).

According to the authors cited above, the acquisition of thermal tolerance is related to increased levels of the HSP70 protein. The exposure of individuals to hyperthermia leads to quick and transient responses at transcriptional and translational levels, which Burdon (1986) considered to be the mechanism responsible for cell survival during the stress period. Among the HSPs, HSP70 is the one that shows the highest levels under stressful situations.

The 70-kDa HSP assists the folding of other proteins. It binds to nascent peptide chains on ribosomes, protecting the hydrophobic surface that would normally be exposed to solvent, thus preventing aberrant folding or aggregation, until the whole peptide chain is synthesized and proper folding occurs (Alberts et al., 2004).

The HSP70 family is the most phylogenetically conserved. Its structure in humans is $72 \%$ homologous with that of drosophila (Hunt and Morimoto, 1985), and HSP70 gene of the chicken is $71 \%$ identical to that of drosophila and $80 \%$ identical to the human gene (Morimoto et al., 1986).

The quail, as most birds, has difficulties dissipating heat. However, almost nothing is known about these proteins in quails and their involvement with stressor agents.

There have been many studies in commercial birds trying to relate the levels of expression of stress proteins with heat tolerance, where the detection of polymorphism in the DNA sequence of stress proteins (HSPs) and its association with heat resistance is one of the challenges of new studies.

The purpose of this study was to analyze a portion of the HSP70 gene in a quail lineage selected for posture, in the quail breeding program at the State University of Maringá, UEM.

\section{MATERIAL AND METHODS}

Ten posture quails (C. japonica), belonging to the Breeding Program in the Animal Science course at the State University of Maringá, were chosen randomly for the study. 
About $100 \mu \mathrm{L}$ blood was drawn from each selected bird by venipuncture of the bronchial vein, and collected directly into microtubes with $100 \mu \mathrm{L}$ sodium citrate $(0.6 \mathrm{M})$, which were kept at $4{ }^{\circ} \mathrm{C}$ and sent to the Molecular Biology Laboratory (UEM) for DNA extraction.

DNA was extracted according to Sambrook et al. (1989), with modifications. After the extraction, the material was analyzed by spectrophotometry at wavelengths of 260 and $280 \mathrm{~nm}$ to determine the protein and DNA concentration in the samples, and their purity was assessed by the $260 / 280 \mathrm{~nm}$ absorbance ratio. The integrity of the DNA was checked by electrophoresis on $0.8 \%$ agar gels, run at $100 \mathrm{~V}$ for $1 \mathrm{~h}$ in a horizontal cube, $20 \times 20 \mathrm{~cm}$ (Scie Plas), using $1 \mathrm{X}$ TBE buffer (500 mM Tris- $\mathrm{HCl}, 60 \mathrm{mM}$ boric acid and $83 \mathrm{mM}$ EDTA), developed in an ethidium bromide bath $(30 \mu \mathrm{L} / \mathrm{L})$ and the image captured with an EDAS UV transilluminator system (Kodak 1D Image Analysis 3.5). Afterward, the samples were standardized at a 50-ng/ $\mu \mathrm{L}$ DNA concentration and then stored at $-20^{\circ} \mathrm{C}$.

The chicken gene was used to amplify the HSP70 portion (Genbank access number J02579; http:/www.ncbi.nlm.nih.gov), which produces a fragment of around $960 \mathrm{bp}$ (Table 1).

\begin{tabular}{|c|c|c|}
\hline Primer & Sequence & Position in the sequence reference \\
\hline Hsp70-P1 & 5' ATGACTGCTCTCATCAAGCGTAA 3, & 1629 \\
\hline Hsp70-P2 & 5, TGGTGAGCTGACAACGTCAACT 3, & 2588 \\
\hline
\end{tabular}

Genomic DNA was amplified in a reaction volume of $20 \mu \mathrm{L}$ containing $1 \mathrm{X}$ Tris- $\mathrm{KCl}$ buffer (20 mM Tris-HCl, $\mathrm{pH} 8.4$, and $50 \mathrm{mM} \mathrm{KCl}$ ), $25 \mathrm{ng}$ specific oligonucleotides (forward and reverse) $(50 \mathrm{ng} / \mu \mathrm{L}), 0.2 \mathrm{mM}$ dNTPs, 1 unit Taq DNA polymerase (Invitrogen) and $50 \mathrm{ng}$ DNA and $1.5 \mathrm{mM} \mathrm{MgCl}$. Each reaction included a negative control to detect possible contamination.

The amplification was as follows: an initial denaturation at $95^{\circ} \mathrm{C}$ for 4 min and 36 cycles at $95^{\circ} \mathrm{C}$ for $30 \mathrm{~s}$, annealing at $60^{\circ} \mathrm{C}$ for $2 \mathrm{~min}$ and extension at $72^{\circ} \mathrm{C}$ for $1.5 \mathrm{~min}$ (extension by Taq DNA polymerase) and a final extension at $72^{\circ} \mathrm{C}$ for $4 \mathrm{~min}$.

Visualization of the polymerase chain reaction (PCR) product was performed using $1.5 \%$ agar gels. Electrophoresis was conducted at $100 \mathrm{~V}$ for $1 \mathrm{~h}$.

A $15.0-\mu \mathrm{L}$ aliquot of the PCR product was applied to the gel wells, diluted in $2 \mu \mathrm{L}$ of running buffer, along with a 100-bp DNA ladder as molecular weight reference for identification of the amplified fragment.

The gels were stained with ethidium bromide $(30 \mu \mathrm{L} / \mathrm{L})$ and visualized in a UV transilluminator. The image was obtained using an EDAS system (Kodak 1D Image Analysis 3.5).

In order to get a sufficient quantity of amplified DNA for later purification and sequencing, amplification was carried out 10 times for sample, using the above PCR protocol.

The PCR products were purified (Invitrogen PureLink Kit) and quantified. About 150 ng of this purified DNA was used for sequencing with the MEGA BACE 1000 Sequencer (Amersham Life Science - USA). The sequences obtained were compared to the gene sequence for the HSP70 protein of chickens, available at GenBank (www.ncbi.nlm.nih.gov), under the access number J02579 (Morimoto et al., 1986). Sequence alignment was performed using BLAST 2 (NCBI) (www.ncbi.nlm.nih.gov). 


\section{RESULTS AND DISCUSSION}

DNA extracted from blood cells shows a 260/280 $\mathrm{nm}$ absorbance ratio varying from 1.6 to 2.3, values near those recommended by Ferreira and Grattapaglia (1995) and Barbosa (1998), indicating that it does not contain excess protein that could interfere in the amplification.

According to agar gel analysis, the DNA showed high-molecular weight quality without signs of degradation in all of the samples.

With the utilization of oligonucleotides specifically designed to amplify a gene region of the $70-\mathrm{kDa}$ stress protein in chicken (Gallus gallus) (HSP70g), it was possible to amplify the stress protein gene in quail (Coturnix japonica) (HSP70c). Figure 1 displays the HSP70g gene sequence (GenBank access number J02579), the oligonucleotides used and the amplified region in the quail gene.

\begin{tabular}{|l|}
\hline 1501 agctgttgct tatggtgccg ctgtgcaagc agctatcctc atgggagaca agtctgaaaa \\
1561 tgtgcaagat ctgctcetgt tggatgtcac cccctgtcc ctgggcatcg agacagctgg \\
1621 tggagtgatg actgctctca tcaagcgtaa caccaccatt cccaccaaac aaacacagac \\
1681 cttcaccacc tactcagaca accagagcag tgtcctcgtc caggtgtatg aaggtgagag \\
1741 ggctatgaca aaggacaaca acttgctggg caagtttgac ctaacaggca tccccccggc \\
1801 acccegtgga gttcctcaga tcgaggtcac ttttgacata gatgctaatg gtatcctgaa \\
1861 cgtcagtgct gtggacaaga gtacagggaa ggagaacaag ataaccatca ccaatgacaa \\
1921 gggtcgcctt agcaaagatg atattgaccg tatggtacaa gaagcagaga aatacaaagc \\
1981 agaggatgaa gccaacagag atagggtggg agccaagaac tccttgagt cgtatactta \\
2041 caacatgaag cagacagtgg aggatgagaa actgaaggga aagatcagtg accaggacaa \\
2101 gcagaaagtg ctcgacaagt gccaggaggt gatcagttcg cttgaccgaa accagatggc \\
2161 agagaaagaa gagtatgagc acaagcagaa agagctggag aaactctgca acccgattgt \\
2221 cacaaaactg taccagggag ctggaggagc tggggcaggt ggctccggtg gcccaaccat \\
2281 tgaagaagta gattaaaaag actcttaaac tatagactgg tttatggaca gtcactccat \\
2341 tcttgcttt atatttttt ctaacgttta aggaaaaacg tcattgccaa taacagagtt \\
2401 tattctgttg ggtgtgtata aaggcaaatc tatcagcttg tggttttgat aaaagggaag \\
2461 gcacgtcctg ctttataagg ttagtaatag acaagttttg ttaattcaga tacagctcct \\
2521 tgtattctgg atgtttgtct ctgtttaaat gtctcttcta aagtaaccac tcgactgttg \\
2581 cagttgacaa gttcaagtt atgctaggaa aaaaaaaact ttgtgaaaga tgagaaatgc \\
2641 caagtgcagc ttctggaaat tttggtaata aataaaattt atttggggat cc \\
\hline
\end{tabular}

Figure 1. A fragment from the chicken HSP70 sequence, described by Morimoto et al. (1986). Underlined region P1 and P2 oligonucleotides; shaded part - amplified region; region in bold - BccI enzyme restriction sites.

With the utilization of $\mathrm{P} 1$ and $\mathrm{P} 2$ oligonucleotides, it was possible to amplify a portion of around $960 \mathrm{bp}$. All animals used demonstrated a positive amplification, using as a reference the process in the chicken.

The amplified fragment sequence of quail HSP70 has shown a 98\% homology with the chicken HSP70 sequence (GenBank access J02579) and 99\% with the helmeted Guinea fowl HSP70 sequence (Numida meleagris) (GenBank access AB096696). Therefore, it was demonstrated that it is practically the same gene, although some alterations have been observed in the DNA sequence. The appearance of transitions and transversions has been demonstrated in the HSP70c fragment, if we consider chicken HSP70 as an ancestral gene. 
In the mutations observed, the transitions appear in higher numbers, being responsible for $75 \%$ of the alterations. The point mutations (15 transitions and 4 transversions) were confirmed with the alignment of the chicken gene HSP70 sequence with two sequences of the quail HSP70 gene, that is, the posture quail individuals that showed a positive amplification were sequenced and the sequences aligned with the chicken HSP70 sequence, which was used as reference.

By examining the chromatograms, it was possible to determine if the alterations pointed out above are confirmed on the sequences among the quail that had the fragment sequenced.

In the chicken sequence, where there is an adenine we can see clearly that in the quail HSP70 sequence (Figure 2) it becomes a guanine, and where the chicken has a guanine there is an adenine in the quail sequence. For this sequenced segment, we can state, as for the other observed transitions and transversions, that there is no doubt with regard to these alterations, since the sequencing was carried out in the absence of impurities. None of the observed alterations produced stop codons.

With the quail gene sequence alignment, an intraspecies alteration was observed. It was shown that for the individual examined, there was a change from a guanine to an adenine and a thymine to a cytosine. This may be an intraspecific polymorphism associated or not with some characteristic of interest, especially the ones related to resistance to different kinds of stress.

An online search was performed to find restriction enzymes capable of digesting the target sequence to detect possible alleles (www.restrictionmapper.org) (Figure 2). For the thymine change to cytosine, the $B c c$ I enzyme was found, whose cutting point coincidentally occurs in the target sequence 5'-CCATC - 3 '. Thus, if the amplified fragment has a thymine opposite to a cytosine, the enzyme will not recognize the sequence and will not digest the fragment.

1628 atg actgctctca tcaagcgtaa caccaccatt cccaccaaac aaacacagac

$1681 \mathrm{cttcaccacc}$ tactcagaca accagagcag tgtcctcgtc caggtgtatg aaggtgagag

1741 ggctatgaca aggacaaca acttgctggg caagtttgac ctaacgggca tcccccagc

1801 acccegtgga gtccctcaga tcgaggtcac tttcgatata gatgctaatg gtatcctgaa

1861 cgtcagtgcc gtggacaaga gtacagggaa ggagaacaag ataaccatca ccaatgacaa

1921 gggtcgcctt agcaaagatg atattgaccg tatggtgcaa gaagcagaga aatacaaagc

1981 agaggatgaa gccaacagag atagggtggg agccaagaac tccctcgagt cgtatactta

2041 caacatgaag cagacggtgg aggatgataa actgaaggga aagatcagcg accaggacaa

2101 gcagaaagtg ctggacaagt gccgggaggt gatcagttgg ctcgaccgaa accagatggc

2161 agagaaagaa gagtatgaac acaagcagaa agagctggag aaactctgca acccgattgt

2221 cacaaaactg taccagggag ctggaggagc tggggcaggt ggctccggtg gtccaaccat

2281 tgaagaagta gattaaaagg actcataaac tatagactgg tttatggaca gtcactccat

$2341 \mathrm{tcttgcttt}$ atatttttt ctaacgttta aggaaaaacg tcattgccaa taacagagtt

2401 tattctgttg ggtgtgtata aaggcaaatc tatcagcttg tggttttgat aaaagggaag

2461 gcacgtcctg ctttataagg ttagtaatag acaagttttg ttaattcaga tacagctcct

2521 tgtattctgg atgtttgtct ctgtttaaat gtctcttcta aagtaaccac tcgactgttg

2581 cagttga

Figure 2. Quail (Coturnix japonica) HSP70 sequenced fragment. The observed alterations on alignment with the chicken HSP70 sequence are highlighted. G can be A, and C can be T. In bold are indicated the possible alleles found in the quail sequence. The enzyme $B c c$ I restriction site is underlined. 
The restriction analyses need to be carried out in a larger group of birds in order to determine if these variations were casual between the two individuals analyzed or if it really does represent a variation within the population.

\section{Peptide sequence}

With the utilization of the BLAST algorithm available at www.ncbi.nlm.nih.gov, the edited DNA sequence was submitted to virtual translation and the peptide sequence aligned with the amino acid sequence deposited in the database at the above website.

The alignment of the amino acid sequence of the stress protein in quail with that of the database confirmed that it was HSP70, besides confirming that the base substitutions are silent mutations.

The aligned amino acid sequences of the quail and chicken (Gallus gallus) protein has demonstrated an identity of $98 \%$. On this alignment, there are two observed changes in amino acids, a glutamic acid (E) for an aspartic acid (D) and a glutamine (Q) for an arginine (R).

The quail HSP70 amino acid sequence shows 99\% homology with the helmeted guinea fowl HSP70 sequence, verifying only one alteration point, namely, one change of arginine (R) for cysteine (S). It is interesting to observe that in both the helmeted guinea fowl and chicken, the identity observed was high, which shows the high degree of conservation in this protein.

Sequence homology has been demonstrated only in this bird, chicken and helmeted guinea fowl, probably because sequences for this gene in other birds have not been deposited in GenBank. Still, even in mammals such as domestic goat or bovines, $84 \%$ homology has been observed in relation to quails.

\section{CONCLUSIONS}

The amplification of a quail HSP70 fragment was possible using specific oligonucleotides. The results revealed alterations in the DNA sequence with the appearance of a possible polymorphism that needs to be studied to determine any association with heat resistance.

\section{REFERENCES}

Alberts B, Johnson A, Lewis J, Raff M, et al. (2004). Biologia Molecular da Célula. Artmed, Porto Alegre.

Barbosa Neto JF (1998). Seleção assistida por marcadores. In: Marcadores moleculares em plantas (Milach SCK, ed.). UFRGS, Porto Alegre, 75-88.

Burdon RH (1986). Heat shock and the heat shock proteins. Biochem. J. 240: 313-324.

Corradello EFA de (1990). Codorna: máquina produtora de carne e ovos: método para sua criação. Ícone, São Paulo, 87.

Ferreira ME and Grattapaglia D (1995). Introdução ao uso de marcadores RAPD e RFLP em análise genética. $3^{\mathrm{a}}$ ed. EMBRAPA-CENARGEN, Brasília, 220.

Hernandes R, Ferro JA, Gonzales E, Macari M, et al. (2002). Resistência à síndrome ascística, competência homeotérmica e níveis de HSP70 no coração e pulmão de frangos de corte. Rev. Bras. Zootec. 31: 1442-1450.

Hunt C and Morimoto RI (1985). Conserved features of eukaryotic hsp70 genes revealed by comparison with the nucleotide sequence of human hsp70. Proc. Natl. Acad. Sci. U. S. A. 82: 6455-6459.

Mazzi CM, Ferro JA, Ferro MIT, Savino VJM, et al. (2003). Polymorphism analysis of the hsp70 stress gene in Broiler chickens (Gallus gallus) of different breeds. Genet. Mol. Biol. 26: 275-282.

Morimoto RI, Hunt C, Huang SY, Berg KL, et al. (1986). Organization, nucleotide sequence, and transcription of the chicken HSP70 gene. J. Biol. Chem. 261: 12692-12699.

Murakami AE and Ariki J (1998). Produção de Codornas Japonesas. Funep, Jaboticabal, 79. 
Oliveira EG (2001). Pontos críticos no manejo e nutrição de codornas. In: Anais do Simpósio sobre Manejo e Nutrição de Aves e Suínos e Tecnologia da Produção de Rações. CBNA, Campinas, 71-96.

Oliveira NTE, Silva MA, Soares RTRN, Fonseca JB, et al. (2002). Exigências de proteína bruta e energia metabolizável para codornas japonesas criadas para a produção de carne. Rev. Bras. Zootec. 31: 675-686.

Parsell DA and Lindquist S (1993). The function of heat-shock proteins in stress tolerance: degradation and reactivation of damaged proteins. Annu. Rev. Genet. 27: 437-496.

Sambrook J, Fritsch EF and Maniatis T (1989). Molecular cloning: a laboratory manual. Cold Spring Harbor, New York. 